\title{
The Wine Effects in Tourism Studies: Mapping the Research Referents
}

\author{
Paulina Campos-Andaur ${ }^{1}$, Karen Padilla-Lobo ${ }^{2}$, Nicolás Contreras-Barraza ${ }^{3}$ (D) , Guido Salazar-Sepúlveda ${ }^{4,5}$ \\ and Alejandro Vega-Muñoz $6, *$ (i)
}

Citation: Campos-Andaur, P.; Padilla-Lobo, K.; Contreras-Barraza, N.; Salazar-Sepúlveda, G.; Vega-Muñoz, A. The Wine Effects in Tourism Studies: Mapping the Research Referents. Sustainability 2022, 14, 2569. https://doi.org/ $10.3390 /$ su14052569

Academic Editors: Gergely Szolnoki, Raul Compes Lopez and

Maximilian Tafel

Received: 11 January 2022

Accepted: 17 February 2022

Published: 23 February 2022

Publisher's Note: MDPI stays neutral with regard to jurisdictional claims in published maps and institutional affiliations.

Copyright: () 2022 by the authors Licensee MDPI, Basel, Switzerland. This article is an open access article distributed under the terms and conditions of the Creative Commons Attribution (CC BY) license (https:/ / creativecommons.org/licenses/by/ $4.0 /)$.
1 Research Group on Economy and Entrepreneurship for Sustainable Development, Universidad Autónoma de Chile, Talca 3460000, Chile; pcamposa@uautonoma.cl

2 Facultad de Ciencias Económicas Administrativas y Contabilidad, Universidad Nacional Autónoma de Honduras, Tegucigalpa 11101, Honduras; kmpadilla@unah.hn

3 Facultad de Economía y Negocios, Universidad Andres Bello, Viña del Mar 2531015, Chile; nicolas.contreras@unab.cl

4 Departamento de Ingeniería Industrial, Facultad de Ingeniería, Universidad Católica de la Santísima Concepción, Concepción 4090541, Chile; gsalazar@ucsc.cl or gusalazar@alumnos.unex.es

5 International Graduate School, University of Extremadura, 10003 Cáceres, Spain

6 Public Policy Observatory, Universidad Autónoma de Chile, Santiago 7500912, Chile

* Correspondence: alejandro.vega@uautonoma.cl

\begin{abstract}
This research provides an empirical overview of articles and authors referring to research on wine tourism, analyzed from 2000 to 2021, and what they contribute to deepening the Sustainable Development Goals (SDGs) 8. The articles were examined through a bibliometric approach based on data from 199 records stored in the Web of Science (JCR), applying traditional bibliometric laws, and using VOSviewer for data processing and metadata. The results highlight an exponential increase in scientific production without interruptions between 2005 and 2020, with a concentration in only 35 highly cited authors, where the hegemony is held by Australia, among the co-authorship networks of worldwide relevance. The main topics observed in the literature are local development through wine tourism, sustainability and nature conservation, and strategies for sustainable development. Finally, there are six articles with great worldwide influence in wine tourism studies that maintain in their entirety the contribution made by researchers affiliated with Australian universities.
\end{abstract}

Keywords: tourism destination; wine tourism; wine tourist; wine routes; enological tourism; destination management organization

\section{Introduction}

The objective of this article is to recognize the global reference authors on research in wine tourism, a growing tourism activity worldwide, which contributes to the economic development of wine regions, with the capacity to boost the economy, stimulate local development, and improve the image of a city [1-11]. The increasing number of articles in journals indexed in WoS databases shows that interest in wine tourism research has increased in the last decade, worldwide, especially in Australia and the United States, with a high degree of sources (journals) and authors with a single article on the subject, and it is interesting to know how this atomized topic of tourism research is constructed [5]. In such a way that it can contribute to the Sustainable Development Goals (SDGs) to promote sustained, inclusive, and sustainable economic growth, full and productive employment, and decent work for all, and to make cities and human settlements inclusive, safe, resilient, and sustainable [12]. In order to achieve the research objective, we used the bibliometric methodology, which allows us to answer questions such as: Which authors are the leading researchers on wine tourism? From which countries do these authors carry out their scientific production? Which are the articles on wine tourism most valued by the scientific 
community? Which wine tourism articles are the most influential for the production of other highly valued articles?

\section{Literature Review}

\subsection{Development Wine Tourist Destination}

The development potential of wine tourism destinations depends on climatic, productive, and strategic factors such as land quality, local and national development strategies for the wine and tourism industry, the attractiveness of the environment, ease of access for tourists, logistics, experiences oriented to consumer satisfaction, tourism education, among others [13-16]. Sustainability in the wine tourism industry has allowed the initiatives to promote economic and cultural growth for the different stakeholders while mitigating the negative effects on the environment $[17,18]$.

One of the strategies for the development of sustainable wine tourism has been the interaction with the different stakeholders, allowing the creation of opportunities for diversification and economic development in the communities of emerging wine regions [2,19-22]. This involves that wine tourism management must be carried out at the level of all stakeholders (government, industry, tourism agencies, residents) to create a truly sustainable concept $[7,23,24]$.

Knowledge perceived by the residents about the tourist activity of the territory has positive impacts on psychological, social, and political empowerment $[2,25,26]$.

\subsection{Wine Tourist}

One of the most relevant actors among the different stakeholders is wine tourists. Research on the behavior of wine tourists contributes to improving the design of differentiating strategies and thus address the needs of different types of customers who usually have similarities in demographic and socioeconomic variables [27-29].

This research indicates that wine tourists show a preference for destinations with cultural attractions, which is a critical success factor in the wine and tourism industry [30]. According to studies, these preferences are based on the quality of the experience perceived by the tourist since it is the central axis of the offer [31,32]. The dimensions that have the greatest impact on the wine tourist's decision to visit are the natural environment, the friendliness of the people in the community, and the diversity of existing wineries, since these influence wine tourism behaviors [33-36] and the competitive value of the region [15,37]. An example of this is found in North Carolina, where winery visit intent and repurchase are influenced by good customer service [38]. Such consumer perceptions allow the industry to expand and define important criteria in the wine landscape to promote wine tourism and rural tourism as a form of on-site consumption. In other cases, the behavior of wine tourists is more linked to the affective image of the destination [39]. Other studies suggest a possible direct link between logistics services and direct sales associated with wine tourism and highlight the importance of strengthening synergies between wine production and tourism to ensure the success of wine tourism offers, as well as international recognition such as UNESCO, which allows them to be promoted $[8,18,40-42]$.

Understanding the wine tourism experience is indispensable for the development of a wine tourism destination where interpersonal facilitators and local attractions that include the sale of artisanal products are three facilitating factors for an adequate perception [29,43-45]. In this context, the use of strategies linked to innovation, creativity and cooperation generate value for the wine tourism market [46,47], promoting a memorable wine drinking experience by making the tourist offer more attractive [8-10,48].

Wine tourist satisfaction is enhanced by the co-creation of experiences and active participation with the various industry stakeholders. Subjective norm influences travel motivation, and attitude, past experiences, and positive emotion are involved in the tourists' desire to participate in a wine tour $[14,28,32,35,39,43,49-54]$.

However, customer satisfaction and appreciation of wine tourism experiences are determined by subjective elements associated with the experience (wine storytelling) and 
participation in winemaking and wine tourism, environment (view and scenery), the authenticity of the experience, and interaction between tourists and tourism employees $[52,53,55]$.

Exploiting the qualities of the territory, the sensory experience, family and ethnic stories, product recognition and awards, environmental protection (UNESCO certifications), and the development of a gastronomic industry all contribute to creating memorable experiences for visitors, making it an excellent promotional tool to attract a greater number of wine tourists $[29,32,36,41,56-62]$.

The most efficient tourist destinations are when cultural, rural, and enological elements are integrated, where the participation and grouping of famous wineries, tourism companies, interpersonal facilitators, and local attractions create a solid local destination image, generating an important source of income for the wineries and their related businesses [14,63-67].

The intention of a wine tourist to return to a destination is related to the attractiveness of the destination, the exposure of the product in wine events, and the cultural emotions perceived by the tourist, causing economic benefits to several territories in the world $[27,35,68-76]$.

Finally, the presence of language barriers, transportation, lack of information, and lack of knowledge to answer queries are limiting factors that impede tourists' visit intentions [28,29].

\section{Materials and Methods}

The main collection of Web of Science (WoS) [77] was used to have a set of articles valued on the basis of citation from the same group of journals, selecting only articles published in journals indexed in Social Science Citation Index (WoS-SSCI) and Science Citation Index Expanded (WoS-SCIE) from a search vector [78] on wine tourism or oenological tourism $\left\{\mathrm{TS}=\left(\right.\right.$ tour ${ }^{*} \mathrm{NEAR} / 0$ (wine OR oenological)) $\}$ and with unrestricted temporal parameters, performing the data extraction and curation on 22 October 2021.

First, the annual exponential growth of the extracted articles was analyzed bibliometrically to ensure the international scientific community's interest (critical mass) in this tourism type, given the growing trend in the documented scientific production, according to Price's law $[79,80]$ (See Table 1). Then, Lotka's law was applied to the authors' production to identify the most prolific group among them and to study them in isolation and in detail, considering the few cases that achieve such an outstanding scientific production among the total number of authors [81]. For identifying the most outstanding articles by the scientific community, the Hirsch index or h-index, calculated as the " $n$ " articles cited " $n$ " times or more by other publications in the WoS core collection, was used $[82,83]$. Increasing the requirements on the article h-index set, a cross-citation analysis (citations exclusively between articles of this set) was added [84], and on the temporally directed graph, the input-output centrality was analyzed to establish the most influential articles $[85,86]$. Finally, information processing and visualization of geographic spatiality, co-authorship, and citation [87-90] were computationally processed with VOSviewer, used in other publications analyzing tourism studies [91-94].

Table 1. Type of data, methods and results.

\begin{tabular}{ccccc}
\hline Type of Data & Unit of Analysis & Unit Numbers & Analytical Methods & Presentations of Results \\
\hline Publication Year & Article & $193^{*}$ & Price's Law, Exponential regression & Figure 1 \\
Author & Article & 199 & Lotka's Law & Figure 2 \\
Author & Article & 199 & Lotka's Law + Co-authorship & Figure 3, Table 2 \\
Country & Article & 199 & Co-authorship & Figure 4 \\
Citation article & Article & 199 & Hirsch index & Table 3 \\
Author & Article & 35 & Co-authorship in h-index & Figure 5 \\
Reference & Article & 35 & Centrality (Graph Theory) & Tables 4 and 5 \\
\hline
\end{tabular}

* Only Articles publishing between 2005 at 2020. 


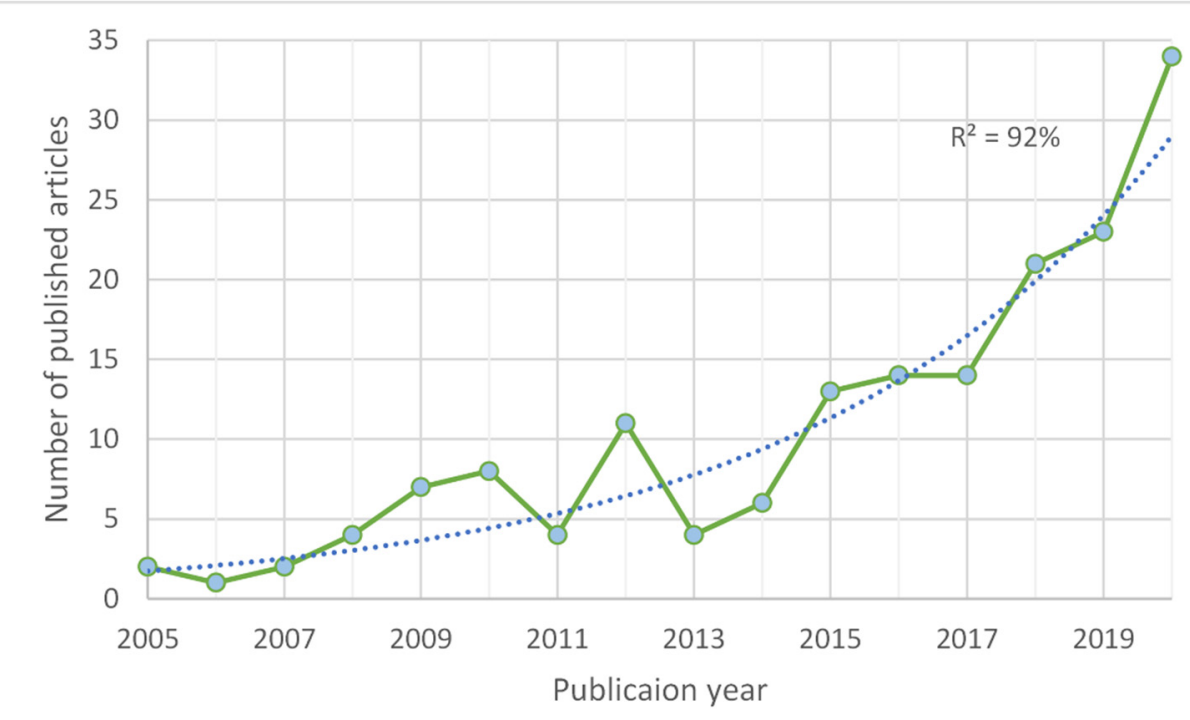

Figure 1. Publications trend on wine tourism studies (2005-2020).

\section{Results}

In relevance terms, the scientific production in wine tourism studies reaches an exponential growth adjusted to $92 \%$, based on the 199 articles retrieved with a publication date between 2000-2021 (including early access documents), with an uninterrupted annual publication in a full-year registry between 2005 and 2020 (see Table S1 included in Supplementary Materials).

This publication set is the result of the research work of 476 authors, whose contribution to the scientific production is distributed between 1 and 7 articles, as shown in Figure 2.

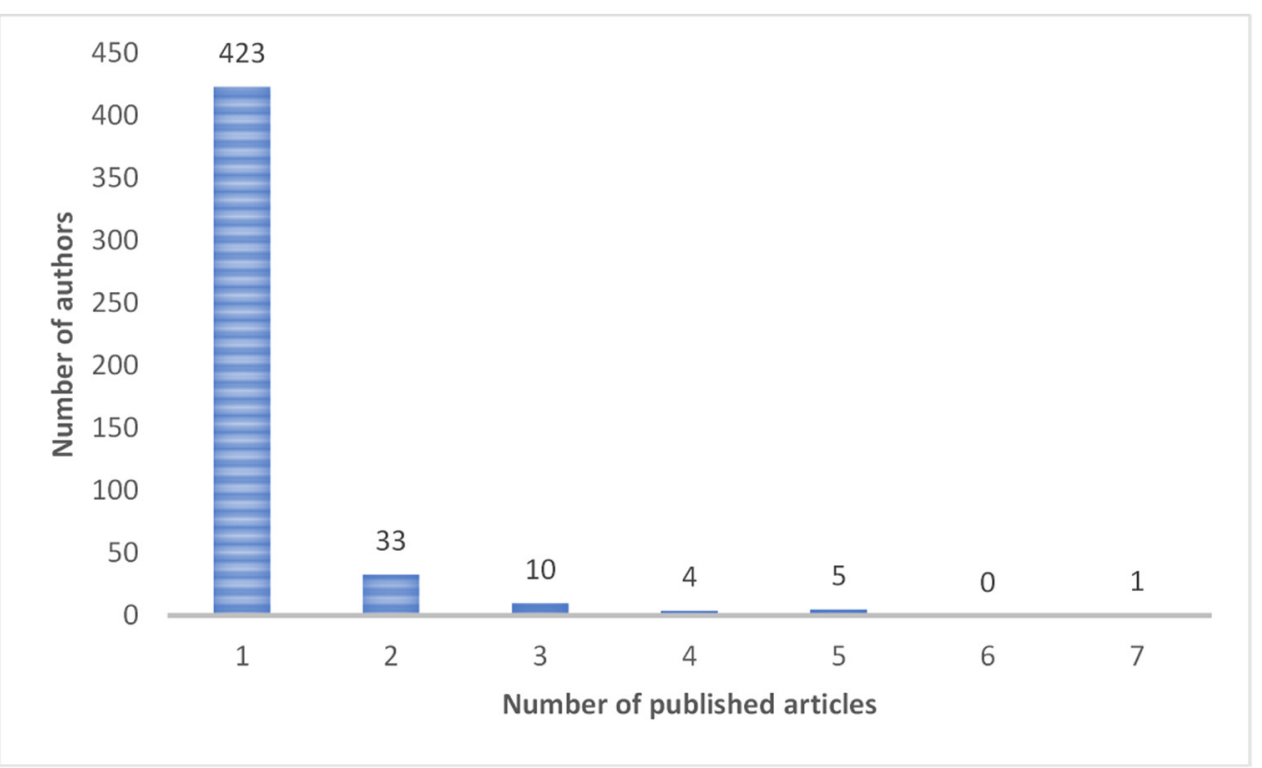

Figure 2. Histogram of publications per authors on wine tourism studies (2000-2021).

As can be seen in Figure 2, 423 authors contribute only one article, with 20 highly productive or prolific authors producing 3 to 7 articles (square root $(476) \approx 20$ ). Thus, Figure 3 details a temporal graph with these 20 prolific authors, indicating with the size of the nodes a proportion with respect to the number of publications of each author and the average date of publications in ascending order from blue to red. 


\section{fountaicjoanna
back, robin $\mathrm{m}$.}

charters, steve festa, giuseppe

yuan, jingxue (jessica)

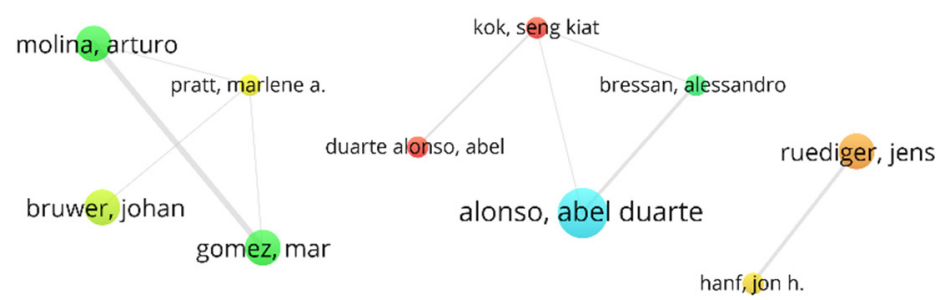

marzo-navaero, mercedes

gu, qiushi

\section{vosviewer}

huang, songshan (sam)

dodd tim $h$.

pedraja-iglesias, marta

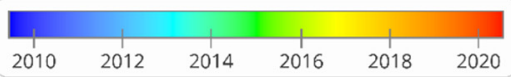

Figure 3. Temporal co-authors graph.

Table 2 adds details for each of the clusters in Figure 3 regarding their institutional and national affiliation.

Table 2. Prolific author clusters and affiliations.

\begin{tabular}{|c|c|c|c|}
\hline Cluster & Authors & Institutional Affiliation & Country Affiliation \\
\hline $\mathrm{C} 01$ & Fountain, J.; Charters, $\mathrm{S}$. & Lincoln Univ.; Sch. Wine and Spirits Business & France; New Zealand \\
\hline $\mathrm{C} 02$ & Back, R. & Univ. Cent Florida & USA \\
\hline $\mathrm{C} 03$ & Festa, G. & Univ Salerno & Italy \\
\hline $\mathrm{C} 04$ & Yuan, J. & Texas Tech Univ. & USA \\
\hline $\mathrm{C} 05$ & Gómez, M.; Molina, A.; Bruwer, J.; Pratt, M. & $\begin{array}{l}\text { Univ. Castilla La Mancha; Univ. Autónoma Chile; } \\
\text { Univ. Adelaide; Univ. South Australia; Univ. } \\
\text { Canterbury; Griffith Univ. }\end{array}$ & Australia; Chile; Spain \\
\hline $\mathrm{C} 06$ & Duarte-Alonso, A.; Kok, S.K.; Bressan, A. & $\begin{array}{c}\text { Auburn Univ.; Curtin Univ.; Edith Cowan Univ.; } \\
\text { RMIT Univ. Vietnam; Univ. Notre Dame Australia, } \\
\text { Univ. Western Sydney }\end{array}$ & Australia; USA; Vietnam \\
\hline $\mathrm{C} 07$ & Ruediger, J; Hanf; J.H. & Hsch Geisenheim Univ.; IU Int Hsch Duales Studium & Germany \\
\hline $\mathrm{C} 08$ & Gu, Q.; Huang, S. & Edith Cowan Univ.; Southeast Univ. & Australia; Peoples R. China \\
\hline $\mathrm{C} 09$ & Marzo-Navarro, M.; Pedraja-Iglesias, M. & Univ. Zaragoza & Spain \\
\hline $\mathrm{C} 10$ & Dodd, T.H. & Texas Tech Univ. & USA \\
\hline
\end{tabular}

Although Table 2 shows a greater presence of affiliations located in the USA and Australia, it also highlights the existence of intercontinental work teams (e.g., Australia, Chile and Spain, and Australia, USA, and Vietnam). In general, the 199 articles present a large interaction of 32 countries (See Figure 4), with the few solo initiatives being those presented by Greece, Croatia and Slovenia, and the Bangladesh-Malaysia duo. The size of the nodes indicates the amount of scientific production from each country or territory; additionally, the colors show the valuation of the scientific production of each geographical origin, expressed in average citations of the articles where the contribution ranges from blue to red with values from 0 to 45 . 


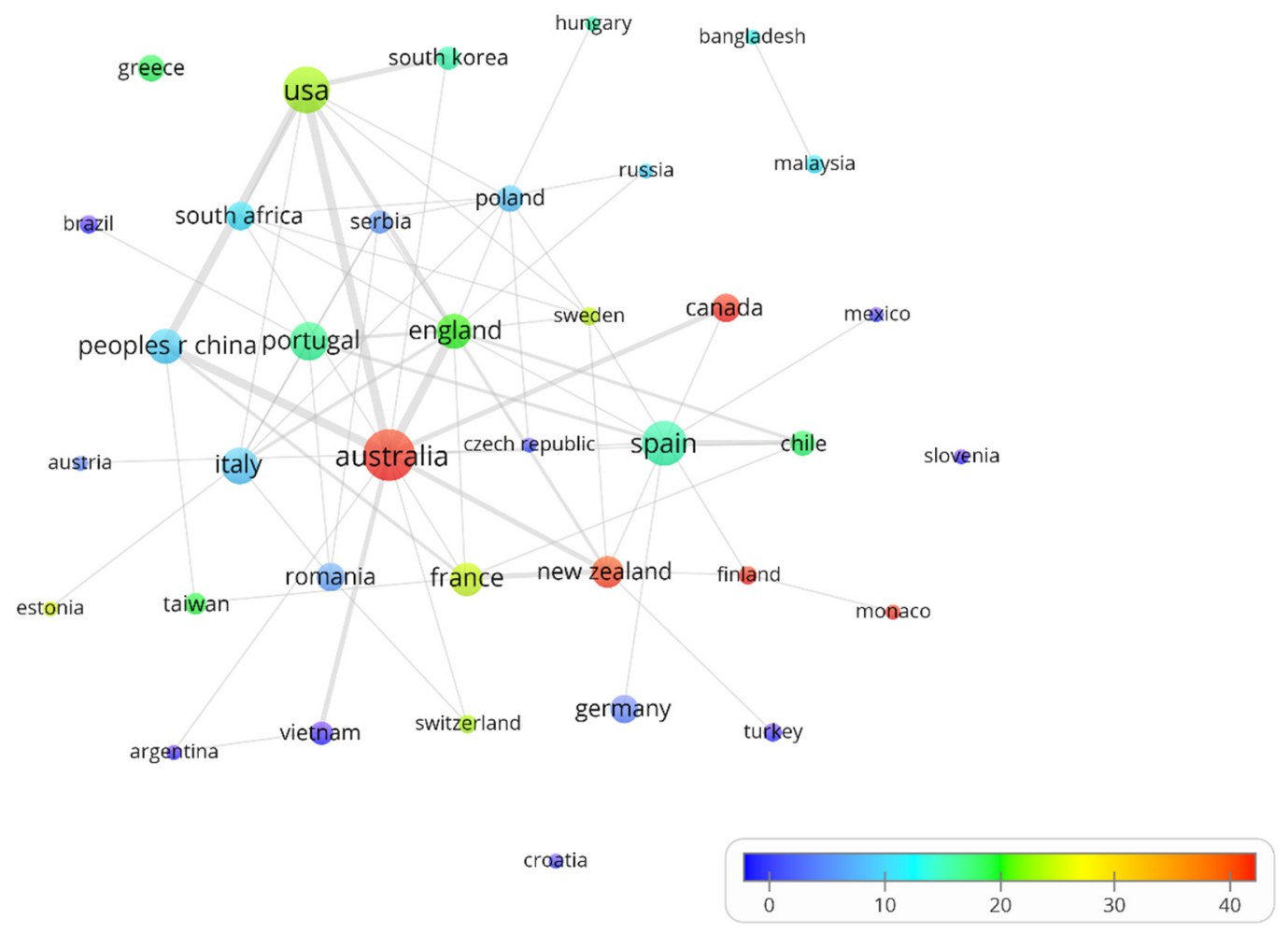

Figure 4. Citation graph in national co-authorship.

The Hirsch index or h-index for the 199 articles is 35, with the articles listed in Table 3.

Table 3. H-index article set description.

\begin{tabular}{|c|c|c|c|c|c|}
\hline Article & First Author & Journal & Publ. Year & Citations & Reference \\
\hline A01 & Getz, D. & Tour. Manag & 2006 & 346 & [30] \\
\hline A02 & Charters, S. & Tour. Manag & 2002 & 291 & [3] \\
\hline A03 & Sparks, B. & Tour. Manag & 2007 & 285 & [26] \\
\hline A04 & Bruwer, J. & Tour. Manag & 2003 & 223 & [34] \\
\hline A05 & Telfer, D.J. & Tour. Manag & 2001 & 141 & [64] \\
\hline A06 & Galloway, G. & Tour. Manag & 2008 & 120 & [73] \\
\hline A07 & Bjork, $\mathrm{P}$. & Int. J. Contemp. Hosp. Manag. & 2016 & 101 & [58] \\
\hline A08 & Bruwer, J. & J. Travel Tour. Mark. & 2012 & 84 & [33] \\
\hline A09 & Barber, N. & J. Travel Tour. Mark. & 2010 & 81 & [20] \\
\hline A10 & Byrd, E.T. & Tourism Manage. & 2016 & 80 & {$[38]$} \\
\hline A11 & Axelsen, M. & J. Travel Res. & 2010 & 78 & [55] \\
\hline A12 & Yuan, J.X. & Int. J. Tour. Res. & 2008 & 76 & [74] \\
\hline A13 & Murray, A. & J. Sustain. Tour. & 2015 & 75 & [59] \\
\hline A14 & Quintal, V.A. & Tourism Manage. & 2015 & 71 & [16] \\
\hline A15 & Charters, S. & J. Travel Res. & 2009 & 70 & [4] \\
\hline A16 & Mitchell, R. & Ann. Touris. Res. & 2012 & 69 & [75] \\
\hline A17 & Fernandes, $\mathrm{T}$. & J. Retail. Consum. Serv. & 2016 & 67 & [31] \\
\hline A18 & Thanh, T.V. & J. Bus. Res. & 2018 & 64 & [2] \\
\hline A19 & Gomez, M. & Tourism Manage. & 2015 & 62 & [9] \\
\hline A20 & Sanchez, A.D. & Eur. Res. Manag. Bus.Econ. & 2017 & 61 & [5] \\
\hline $\mathrm{A} 21$ & Marzo-Navarro, M. & Int. J. Contemp. Hosp. Manag. & 2012 & 60 & {$[62]$} \\
\hline $\mathrm{A} 22$ & Qiu, H.Q.Z. & Int. J. Contemp. Hosp. Manag. & 2013 & 56 & [11] \\
\hline A23 & Martins, J. & J. Destin. Mark. Manag. & 2017 & 53 & [76] \\
\hline A24 & Scherrer, P. & Int. J. Tour. Res. & 2009 & 50 & [65] \\
\hline A25 & Carlsen, J. & J. Hosp. Tour. Res. & 2015 & 47 & [37] \\
\hline A26 & Xu, S.Y. & Tourism Manage. & 2016 & 45 & {$[66]$} \\
\hline $\mathrm{A} 27$ & Lee, T.H. & Leis. Stud. & 2012 & 45 & [49] \\
\hline
\end{tabular}


Table 3. Cont.

\begin{tabular}{cccccc}
\hline Article & First Author & Journal & Publ. Year & Citations & Reference \\
\hline A28 & Marzo-Navarro, M. & Int. J. Contemp. Hosp. Manag. & 2009 & 45 & {$[61]$} \\
A29 & Bras, J.M. & Serv. Ind. J. & 2010 & 2012 & 43 \\
A30 & Hojman, D.E. & J. Bus. Res. & 2014 & 41 & {$[67]$} \\
A31 & Pratt, M.A. & J. Travel Tour. Mark. & 2000 & 41 & {$[23]$} \\
A32 & O'Neill, P. & Geoforum & 2012 & 38 & {$[21]$} \\
A33 & Gomez, M. & Int. J. Tour. Res. & 2014 & 37 & {$[10]$} \\
A34 & Nella, A. & J. Travel Tour. Mark. & 2015 & 36 & {$[54]$} \\
A35 & Alonso, A.D. & Int. J. Tour. Res. & [7] \\
\hline
\end{tabular}

Figure 5 shows the interaction between these 35 high citation articles ( $\geq 35$ citations) reaching 346 citations (A01), the colors of the nodes show the temporal variation from 2001 to 2017, and the nodes size the number of connections either by a received citation or by citing other articles in the set.

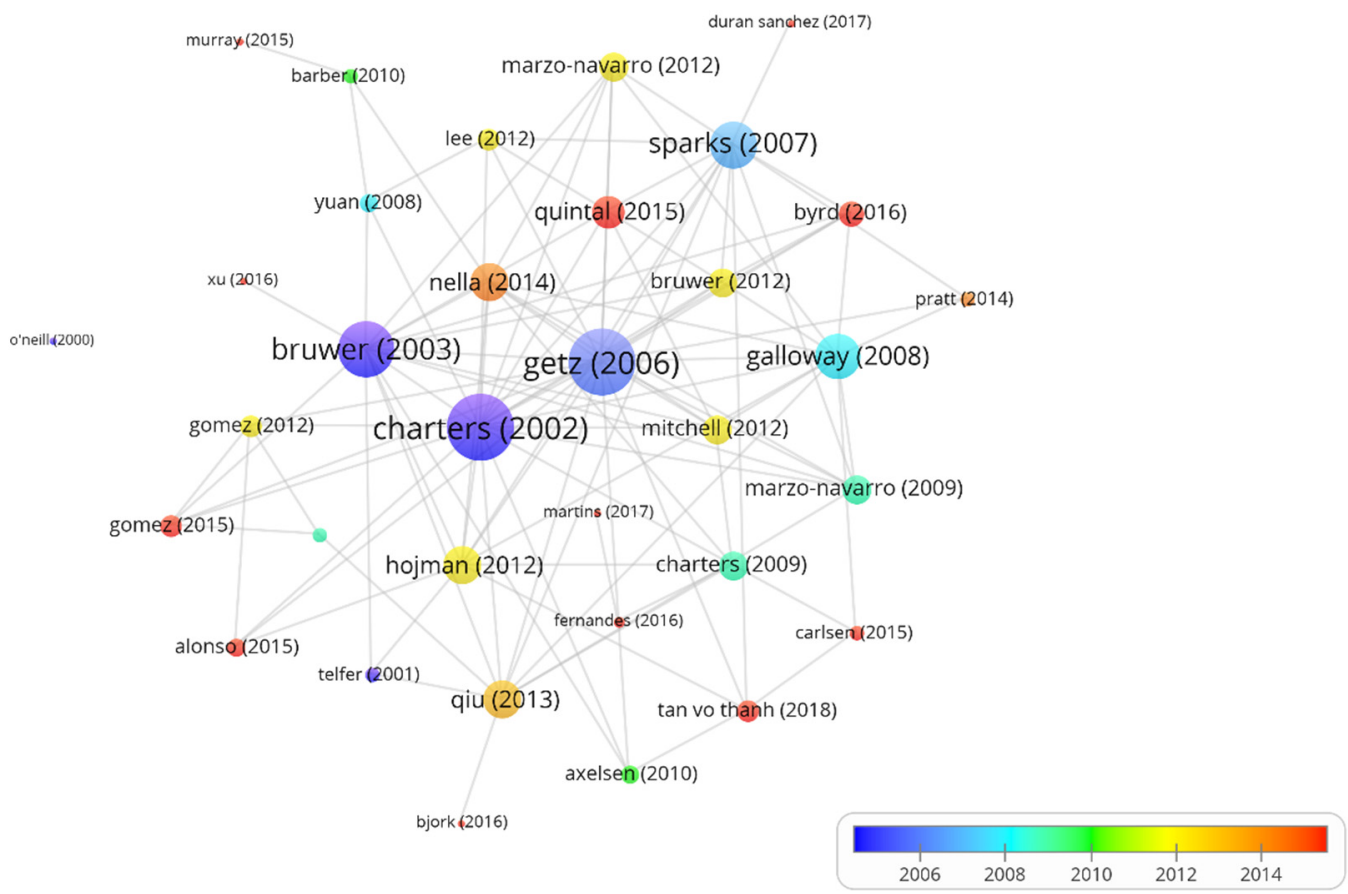

Figure 5. Cross-citation temporal graph between h-index articles.

The above leads to the directed centrality calculation of articles with the highest incoming and outgoing time connection ciphers within the set of 35 articles in the h-index set (See Table 4).

There are two article subsets, some that are well supported in this set of highly cited articles, and others that are recognized as influential publications in this elite article set (See Table 5). It is also noteworthy that the temporal segregation of the publications with 2009 as the break year, where supported and influential articles are found, before that date, all the articles in the set are influential (2002-2008), and after that year, all the articles in the set are supported (2010-2015). 
Table 4. Centrality degrees and node type for articles in the h-index set.

\begin{tabular}{|c|c|c|c|c|c|c|c|}
\hline Article & First Author & $\begin{array}{l}\text { Publ. } \\
\text { Year }\end{array}$ & Citations & $\begin{array}{c}\text { All } \\
\text { Links }\end{array}$ & $\begin{array}{l}\text { Centrality } \\
\text { In-Degree }\end{array}$ & $\begin{array}{l}\text { Centrality } \\
\text { Out-Degree }\end{array}$ & $\begin{array}{l}\text { Type } \\
\text { Node }\end{array}$ \\
\hline A01 & Getz, D. [30] & 2006 & 346 & 20 & 2 & 18 & Influence \\
\hline $\mathrm{A} 02$ & Charters, S. [3] & 2002 & 291 & 20 & 0 & 20 & Influence \\
\hline A03 & Sparks, B. [26] & 2007 & 285 & 13 & 2 & 11 & Influence \\
\hline A04 & Bruwer, J. [34] & 2003 & 223 & 16 & 2 & 14 & Influence \\
\hline A06 & Galloway, G. [73] & 2008 & 120 & 12 & 2 & 10 & Influence \\
\hline A08 & Bruwer, J. [33] & 2012 & 84 & 7 & 5 & 2 & Support \\
\hline A14 & Quintal, V.A. [16] & 2015 & 71 & 8 & 8 & 0 & Support \\
\hline A15 & Charters, S. [4] & 2009 & 70 & 7 & 1 & 6 & Influence \\
\hline A16 & Mitchell, R. [75] & 2012 & 69 & 7 & 5 & 2 & Support \\
\hline A21 & Marzo-Navarro, M. [62] & 2012 & 60 & 7 & 5 & 2 & Support \\
\hline A22 & Qiu, H.Q.Z. [11] & 2013 & 56 & 10 & 9 & 1 & Support \\
\hline A 28 & Marzo-Navarro, M. [61] & 2009 & 45 & 7 & 5 & 2 & Support \\
\hline A30 & Hojman, D.E. [23] & 2012 & 43 & 10 & 7 & 3 & Support \\
\hline A34 & Nella, A. [54] & 2014 & 37 & 10 & 10 & 0 & Support \\
\hline
\end{tabular}

Table 5. Influential articles within the h-index set.

\begin{tabular}{|c|c|c|c|c|c|}
\hline Article & Authors & $\begin{array}{l}\text { Publ. } \\
\text { Year }\end{array}$ & Citations & $\begin{array}{l}\text { Centrality } \\
\text { Out-Degree }\end{array}$ & Affiliation \\
\hline A01 & Getz, D.; Brown, G. [30] & 2006 & 346 & 18 & Univ. Calgary (CA); Univ. S. Australia (AU) \\
\hline A02 & Charters, S; Ali-Knight, J. [3] & 2002 & 291 & 20 & Edith Cowan Univ. (UA); Curtin Univ (AU) \\
\hline A03 & Sparks, B. [26] & 2007 & 285 & 11 & Griffith Univ (AU) \\
\hline A04 & Bruwer, J. [34] & 2003 & 223 & 14 & Univ Adelaide (AU) \\
\hline A06 & $\begin{array}{l}\text { Galloway, G; Mitchell, R; Getz, D; } \\
\text { Crouch, G; Ong, B. [73] }\end{array}$ & 2008 & 120 & 10 & $\begin{array}{l}\text { La Trobe Univ. (AU); Univ. Otago (NZ); Univ. } \\
\text { Calgary, (CA) }\end{array}$ \\
\hline A15 & Charters, S.; Fountain, J; Fish, N. [4] & 2009 & 70 & 6 & $\begin{array}{l}\text { Reims Management Sch. (FR); Lincoln Univ. } \\
\text { (NZ); Swinburne Univ. Technol. (AU) }\end{array}$ \\
\hline
\end{tabular}

AU: Australia, CA: Canada, FR: France, and NZ: New Zealand.

Finally, this set of six articles with great worldwide influence in wine tourism studies maintains in its entirety the contribution made by researchers affiliated with Australian universities. Within the 34 citation possibilities within the h-index, they are cited 6 to 20 times.

\section{Discussion}

This article deepens the idea of an emerging theme in tourism studies around the wine industry, as highlighted by Acevedo et al. [91]. Most of the scientific production refers to empirical articles with data collection on wine tourism consumers, stakeholders, and logistics studies; we found a bibliometric study developed by Sanchez, Del Rio, and Alvarez, which studies two databases (Wos and Scopus) and generates some conclusions that we have deepened and updated in our research. Although their study by Sanchez et al. [5] points out that the research is related to the business sciences, it does not provide in-depth information on its characteristics, however, in our research, we can observe through the literature review that the most influential papers take commercial themes, such as the importance of the destination brand, the impact of wine production and its relationship with wine tourism, and the relationship with the environment, taking much strength from the territory. We agree with the study that Anglo-Saxon countries have the greatest influence, but it is clearly Australia that stands out above all others. Another point of coincidence with this article is that at the level of the h-indexed articles analyzed, the journals Tourism Management and Journal of Travel and Tourism Marketing also stand out.

Finally, we disagree with one of his conclusions where he points out the multidisciplinary nature of wine tourism research up to that moment since it is possible to observe a concentration on commercial topics and that there is still a long way to go by having the possibility of incorporating with greater strength areas such as biology, architecture and construction, psychological and social aspects, and technological aspects that complement the current domain of business. 
This is based on the studies of enological tourism with the greatest influence [3,26,30,35,73], developed topics that over time covered commercial issues, consumer characteristics, strategic plans, territory, and expansion policies, with very few studies progressing beyond the commercial area.

These influential studies do not consider gender issues in the choice of services, the incorporation of diversity in all its manifestations and in the effect of consumption of tourist destinations, inclusive policies for different disabilities, and cultural integration of marginalized populations. These issues were already present in the past but have not been clearly and forcefully evidenced. Another aspect that is very absent among the most frequently cited $[3,26,30,34,73]$ is the effects of technology and its relationship with the development of wine tourism and its relationship with environmental conservation.

\section{Conclusions}

The purpose of this study was to provide an empirical overview of the authors and research articles on wine tourism, analyzed from 2000 to 2021, and contribute to the Sustainable Development Goals (SDGs) 8. In the first stage, an exhaustive bibliometric analysis was carried out, which resulted in the main topics observed in the literature being local development through wine tourism, sustainability and nature conservation, and strategies for its sustainable development, service experiences on wine tourism, and its relationship with stakeholders. The methodology used was a bibliometric approach based on data from 199 records stored in the Web of Science (JCR), applying traditional bibliometric laws, and using VOSviewer for data and metadata processing. Among the results, we highlighted an exponential increase in scientific production without interruptions between 2005 and 2020, finding 35 authors with higher productivity that led the research in the wine industry, where Australia and the United States are the countries that concentrate the scientific production of the authors, among the co-authorship networks of worldwide relevance. Among the 35 articles in the h-index analysis, Getz and Brown [30] published in Tourism Management, with the most citations in the main WOS collection, stands out. However, the most influential article within the h-index is Charters and Ali-Knight [3], also published in Tourism Management.

It is recommended for future research to consider gender issues in the choice of services, fair labor, and price, the incorporation of diversity in all its manifestations and in the effect of consumption of tourist destinations, inclusive policies for different disabilities, and cultural integration of marginalized populations. The limitation of this research corresponds to the use of 199 articles published in journals indexed in Social Science Citation Index (WoS-SSCI) and Science Citation Index Expanded (WoS-SCIE), preferring this elitisation of the sample to work with journals of greater recognition in the scientific community $[95,96]$.

Supplementary Materials: The following supporting information can be downloaded at: https: / / www.mdpi.com/article/10.3390/su14052569/s1, Table S1: WT.txt.

Author Contributions: Conceptualization, P.C.-A., K.P.-L. and G.S.-S.; methodology, A.V.-M.; software, A.V.-M.; validation, G.S.-S.; formal analysis, A.V.-M.; writing-original draft preparation, N.C.-B., P.C.-A., K.P.-L. and G.S.-S.; writing-review and editing, N.C.-B., G.S.-S. and K.P.-L.; visualization, A.V.-M.; project administration, P.C.-A. and K.P.-L.; funding acquisition, N.C.-B., G.S.-S. and A.V.-M. All authors have read and agreed to the published version of the manuscript.

Funding: The article processing charge (APC) was partially funded by Universidad Católica de la Santísima Concepción.

Institutional Review Board Statement: Not applicable.

Informed Consent Statement: Not applicable.

Data Availability Statement: The analyzed dataset has been included as Supplementary Materials. 


\begin{abstract}
Acknowledgments: The authors would like to thank the Ph.D. program in Economic, Business and Social Sciences at the Sevilla University (Spain). The program where the researcher Paulina Campos-Andaur is studying her Ph.D. with the research line in economy, studying issues of Tourism sector economics, under the direction of Professor Roció Iñiguez-Ovando and Professor Alejandro Vega-Muñoz, and the tutorship of Professor José Manuel Cansino Muñoz-Repiso.
\end{abstract}

Conflicts of Interest: The authors declare no conflict of interest.

\title{
References
}

1. Bauman, M.J.; Yuan, J.; Williams, H.A. Developing a measure for assessing tourists' empathy towards natural disasters in the context of wine tourism and the 2017 California wildfires. Curr. Issues Tour. 2019, 23, 2476-2491. [CrossRef]

2. Thanh, T.; Kirova, V. Wine tourism experience: A netnography study. J. Bus. Res. 2017, 83, 30-37. [CrossRef]

3. Charters, S.; Ali-Knight, J. Who is the wine tourist? Tour. Manag. 2002, 23, 311-319. [CrossRef]

4. Charters, S.; Fountain, J.; Fish, N. You Felt Like Lingering ... Experiencing Real Service at the Winery Tasting Room. J. Travel Res. 2009, 48, 122-134. [CrossRef]

5. Sanchez, A.D.; Rama, M.D.; Garcia, J.A. Bibliometric analysis of publications on wine tourism in the databases Scopus and WoS. Eur. Res. Manag. Bus. Econ. 2017, 23, 8-15. [CrossRef]

6. Alonso, A.D. Wine as a unique and valuable resource. An exploratory study of wine consumers on La Palma Island. Br. Food. J. 2015, 117, 2757-2776. [CrossRef]

7. Alonso, A.D.; Bressan, A.; O'Shea, M.; Krajsic, V. Perceived Benefits and Challenges to Wine Tourism Involvement: An International Perspective. Int. J. Tour. Res. 2015, 17, 66-81. [CrossRef]

8. Gomez, J.; Tascon, A.; Ayuga, F. Systematic layout planning of wineries: The case of Rioja region (Spain). J. Agric. Eng. 2018, 49, 34-41. [CrossRef]

9. Gomez, M.; Lopez, C.; Molina, A. A model of tourism destination brand equity: The case of wine tourism destinations in Spain. Tour. Manag. 2015, 51, 210-222. [CrossRef]

10. Gomez, M.; Molina, A. Wine Tourism in Spain: Denomination of Origin Effects on Brand Equity. Int. J. Tour. Res. 2012, 14, 353-368. [CrossRef]

11. Qiu, H.Q.; Yuan, J.X.; Ben, H.B.; Hung, K. Wine tourism phenomena in China: An emerging market. Int. J. Contemp. Hosp. Manag. 2013, 25, 1115-1134. [CrossRef]

12. Wu, J.; Guo, S.; Huang, H.; Liu, W.; Xiang, Y. Information and Communications Technologies for Sustainable Development 347 Goals: State-of-the-Art, Needs and Perspectives. IEEE Commun. Surv. Tutor. 2018, 20, 2389-2406. [CrossRef]

13. Pijet-Migon, E.; Migon, P. Linking Wine Culture and Geoheritage-Missing Opportunities at European UNESCO World Heritage Sites and in UNESCO Global Geoparks? A Survey of Web-Based Resources. Geoheritage 2021, 13, 71. [CrossRef]

14. Back, R.M.; Lowry, L.L.; Higgins, L.M. Exploring a wine farm micro-cluster: A novel business model of diversified ownership. J. Vacat. Mark. 2021, 27, 103-116. [CrossRef]

15. Teixeira, S.J.; Ferreira, J.M.; Almeida, A.; Parra-Lopez, E. Tourist events and satisfaction: A product of regional tourism competitiveness. Tour. Rev. 2019, 74, 943-977. [CrossRef]

16. Quintal, V.A.; Thomas, B.; Phau, I. Incorporating the winescape into the theory of planned behaviour: Examining 'new world' wineries. Tour. Manag. 2015, 46, 596-609. [CrossRef]

17. Sun, Y.Y.; Drakeman, D. The double-edged sword of wine tourism: The economic and environmental impacts of wine tourism in Australia. J. Sustain. Tour. 2021. [CrossRef]

18. Smyczek, S.; Festa, G.; Rossi, M.; Monge, F. Economic sustainability of wine tourism services and direct sales performanceEmergent profiles from Italy. Br. Food J. 2020, 122, 1519-1529. [CrossRef]

19. Alonso, A.D.; Liu, Y. Wine tourism development in emerging Western Australian regions. Int. J. Contemp. Hosp. Manag. 2010, 22, 245-262. [CrossRef]

20. Barber, N.; Taylor, D.C.; Deale, C.S. Wine Tourism, Environmental Concerns, and Purchase Intention. J. Travel Tour. Mark. 2010, 27, 146-165. [CrossRef]

21. O'Neill, P.; Whatmore, S. The business of place: Networks of property, partnership and produce. Geoforum 2000, 31, 121-136. [CrossRef]

22. Pratt, M.A.; Sparks, B. Predicting Wine Tourism Intention: Destination Image and Self-congruity. J. Travel Tour. Mark. 2014, 31, 443-460. [CrossRef]

23. Hojman, D.E.; Hunter-Jones, P. Wine tourism: Chilean wine regions and routes. J. Bus. Res. 2012, 65, 13-21. [CrossRef]

24. Cloutier, L.M.; Renard, L.; Arcand, S. Conceptualización económica colectiva de las rutas de la sidra y el vino por parte de los grupos de interés. J. Wine Econ. 2019, 14, 383-391. [CrossRef]

25. Nave, A.; Laurett, R.; do Paço, A. Relation between antecedents, barriers and consequences of sustainable practices in the wine tourism sector. J. Destin. Mark. Manag. 2021, 20, 100584. [CrossRef]

26. Sparks, B. Planning a wine tourism vacation? Factors that help to predict tourist behavioural intentions. Tour. Manag. 2007, 28, 1180-1192. [CrossRef] 
27. Alfonso, C.; Silva, G.M.; Goncalves, H.M.; Duarte, M. The role role of motivations and involvement in wine tourists' intention to return: SEM and fsQCA findings. J. Bus. Res. 2018, 89, 313-321. [CrossRef]

28. Ye, B.H.; Zhang, H.Q.; Yuan, J. Intentions to Participate in Wine Tourism in an Emerging Market: Theorization and Implications. J. Hosp. Tour. Res. 2014, 41, 1007-1031. [CrossRef]

29. Gu, Q.; Qiu, H.; King, B.E.; Huang, S. Understanding the wine tourism experience: The roles of facilitators, constraints, and involvement. J. Vacat. Mark. 2019, 26, 211-229. [CrossRef]

30. Getz, D.; Brown, G. Critical success factors for wine tourism regions: A demand analysis. Tour. Manag. 2006, 27, 146-158. [CrossRef]

31. Fernandes, T.; Cruz, M. Dimensiones y resultados de la calidad de la experiencia en el turismo: El caso de las bodegas de vino de Oporto. J. Retail. Consum. Serv. 2016, 31, 371-379. [CrossRef]

32. Brochado, A.; Stoleriu, O.; Lupu, C. Wine tourism: A multisensory experience. Curr. Issues Tour. 2019, 24, 597-615. [CrossRef]

33. Bruwer, J.; Lesschaeve, I. wine tourists' destination region brand image perception and antecedents: Conceptualization of a winescape framework. J. Travel Tour. Mark. 2012, 29, 611-628. [CrossRef]

34. Bruwer, J. South African wine routes: Some perspectives on the wine tourism industry's structural dimensions and wine tourism product. Tour. Manag. 2003, 24, 423-435. [CrossRef]

35. Bruwer, J.; Prayag, G.; Disegna, M. Why wine tourists visit cellar doors: Segmenting motivation and destination image. Int. J. Tour. Res. 2018, 20, 355-366. [CrossRef]

36. Frost, W.; Frost, J.; Strickland, P.; Maguire, J.S. Buscando una ventaja competitiva en el enoturismo: Patrimonio y narración en la puerta de la bodega. Int. J. Hosp. Manag. 2020, 87, 102460. [CrossRef]

37. Carlsen, J.; Boksberger, P. Enhancing consumer value in wine tourism. J. Hosp. Tour. Res. 2015, 39, 132-144. [CrossRef]

38. Byrd, E.T.; Canziani, B.; Hsieh, Y.C.; Debbage, K.; Sonmez, S. Wine tourism: Motivating visitors through core and supplementary services. Tour. Manag. 2016, 52, 19-29. [CrossRef]

39. Back, R.M.; Tasci, A.D.; Milman, A. Experiential consumption of a South African wine farm destination as an agritourism attraction. J. Vacat. Mark. 2020, 26, 57-72. [CrossRef]

40. Okumus, B.; Mehraliyev, F.; Ma, F.; Köseoglu, M.A. Intellectual connections in food tourism literature: A co-citation approach. Int J. Tour. Res. 2020, 23, 220-237. [CrossRef]

41. Dancausa Millán, M.G.; Millán Vázquez de la Torre, M.G.; Hernández Rojas, R. Analysis of the demand for gastronomic tourism in Andalusia (Spain). PLoS ONE 2021, 16, e0246377. [CrossRef] [PubMed]

42. Bitsch, L.; Hanf, J.H.; Rüdiger, J. An innovative price-setting approach: A pay-what-you-want experiment. Br. Food J. 2021, 122, 2481-2496. [CrossRef]

43. Wu, G.; Liang, L. Examining the effect of potential tourists' wine product involvement on wine tourism destination image and travel intention. Curr. Issues Tour. 2020. [CrossRef]

44. Bachman, J.R.; Hull, J.S.; Haecker, S. Millennials are not all the same: Examining millennial craft brewery and winery visitors' social involvement, self-image, and social return. Int. J. Tour. Res. 2021, 23, 123-133. [CrossRef]

45. Duan, B.; Arcodia, C.; Ma, E.; Hsiao, A. Understanding wine tourism in China using an integrated product-level and experience economy framework. Asia Pac. J. Tour. Res. 2018, 23, 949-960. [CrossRef]

46. Tommasetti, A.; Festa, G. An analysis of wine tourism in Italy from a strategic service-based perspective. Serv. Sci. 2014, 6, 122-135. [CrossRef]

47. Salvagni, J.; Nodari, C.H.; Valduga, V. Cooperation, Innovation and Tourism in the Grape and Wine Region, Brazil. Cuad. Desarro. Rural. 2020, 17. [CrossRef]

48. Priilaid, D.; Ballantyne, R.; Packer, J.A. blue ocean strategy for developing visitor wine experiences: Unlocking value in the Cape region tourism market. J. Hosp. Tour. Manag. 2020, 43, 91-99. [CrossRef]

49. Lee, T.H.; Chang, Y.S. The influence of experiential marketing and activity involvement on the loyalty intentions of wine tourists in Taiwan. Leis. Stud. 2012, 31, 103-121. [CrossRef]

50. Lee, K.; Madanoglu, M.; Ko, J.Y. Exploring key service quality dimensions at a winery from an emerging market's perspective. Br. Food J. 2016, 118, 2981-2996. [CrossRef]

51. Lee, S.; Bruwer, J.; Song, H. Experiential and involvement effects on the Korean wine tourist's decision-making process. Curr. Issues Tour. 2017, 20, 1215-1231. [CrossRef]

52. Rahman, M.S.; Zaman, M.H.; Hassan, H.; Wei, C.C. Tourist's preferences in selection of local food: Perception and behavior embedded model. Tour. Rev. 2018, 73, 111-132. [CrossRef]

53. Rachao, S.A.; Breda, Z.D.; Fernandes, C.D.; Joukes, V.N. Drivers of experience co-creation in food-and-wine tourism: An exploratory quantitative analysis. Tour. Manag. Perspect. 2021, 37, 100783. [CrossRef]

54. Nella, A.; Christou, E. Segmenting Wine Tourists on the Basis of Involvement with Wine. J. Travel Tour. Mark. 2014, 31, 783-798. [CrossRef]

55. Axelsen, M.; Swan, T. Designing Festival Experiences to Influence Visitor Perceptions: The Case of a Wine and Food Festival. J. Travel Res. 2010, 49, 436-450. [CrossRef]

56. Vukovic, D.B.; Maiti, M.; Vujko, A.; Shams, R. Residents' perceptions of wine tourism on the rural destinations development. Br. Food J. 2020, 122, 2739-2753. [CrossRef] 
57. Eustice, C.; McCole, D.; Rutty, M. The impact of different product messages on wine tourists' willingness to pay: A nonhypothetical experiment. Tour. Manag. 2019, 72, 242-248. [CrossRef]

58. Bjork, P.; Kauppinen-Raisanen, H. Local food: A source for destination attraction. Int. J. Contemp. Hosp. Manag. 2016, 28, 177-194. [CrossRef]

59. Murray, A.; Kline, C. Rural tourism and the craft beer experience: Factors influencing brand loyalty in rural North Carolina, USA. J. Sustain. Tour. 2015, 23, 1198-1216. [CrossRef]

60. Marzo-Navarro, M.; Pedraja-Iglesias, M. Wine tourism development from the perspective of the potential tourist in Spain. Int. J. Contemp. Hosp. Manag. 2009, 21, 816-835. [CrossRef]

61. Marzo-Navarro, M.; Pedraja-Iglesias, M. Profile of a wine tourist and the correspondence between destination and preferred wine: A study in Aragon, Spain. J. Travel Tour. Mark. 2009, 26, 670-687. [CrossRef]

62. Marzo-Navarro, M.; Pedraja-Iglesias, M. Critical factors of wine tourism: Incentives and barriers from the potential tourist's perspective. Int. J. Contemp. Hosp. Manag. 2012, 24, 312-334. [CrossRef]

63. Guzel, O.; Ehtiyar, R.; Ryan, C. The Success Factors of wine tourism entrepreneurship for rural area: A thematic biographical narrative analysis in Turkey. J. Rural Stud. 2021, 84, 230-239. [CrossRef]

64. Telfer, D.J. Strategic alliances along the Niagara Wine Route. Tour. Manag. 2001, 22, 21-30. [CrossRef]

65. Scherrer, P.; Alonso, A.; Sheridan, L. Expanding the Destination Image: Wine Tourism in the Canary Islands. Int. J. Tour. Res. 2009, 11, 451-463. [CrossRef]

66. Xu, S.Y.; Barbieri, C.; Anderson, D.; Leung, Y.F.; Rozier-Rich, S. Residents' perceptions of wine tourism development. Tour. Manag. 2016, 55, 276-286. [CrossRef]

67. Bras, J.M.; Costa, C.; Buhalis, D. Network analysis and wine routes: The case of the Bairrada Wine Route. Serv. Ind. J. 2010, 30, 1621-1641. [CrossRef]

68. McFarlane, J.; Grant, B.; Blackwell, B.; Mounter, S. Combining amenity with experience: Exploring the hidden capital of a winescape experience. Tour. Econ. 2017, 23, 1076-1095. [CrossRef]

69. Pelegrin, J.; Gonzalez-Menorca, C.; Meraz, L. The influence of the emotions produced by the wine offer, winery visits, and wine news on wine purchase intent in tourists. Span. J. Agric. Res. 2019, 17. [CrossRef]

70. Kruger, M.; Viljoen, A. Terroir wine festival visitors: Uncorking the origin of behavioural intentions. Curr. Issues Tour. 2021, 24, 616-636. [CrossRef]

71. Gomez, M.; Molina, A.; Esteban, A. What are the main factors attracting visitors to wineries? A PLS multi-group comparison. Qual. Quant. 2013, 47, 2637-2657. [CrossRef]

72. Gomez, M.; Pratt, M.A.; Molina, A. Wine tourism research: A systematic review of 20 vintages from 1995 to 2014 . Curr. Issues Tour. 2019, 22, 2211-2249. [CrossRef]

73. Galloway, G.; Mitchell, R.; Getz, D.; Crouch, G.; Ong, B. Sensation seeking and the prediction of attitudes and behaviours of wine tourists. Tour. Manag. 2008, 29, 950-966. [CrossRef]

74. Yuan, J.X.; Morrison, A.M.; Cai, L.P.; Linton, S. A Model of Wine Tourist Behaviour: A Festival Approach. Int. J. Tour. Res. 2008, 10, 207-219. [CrossRef]

75. Mitchell, R.; Charters, S.; Albrecht, J.N. Cultural systems and the wine tourism product. Ann. Tour. Res. 2012, 39, 311-335. [CrossRef]

76. Martins, J.; Goncalves, R.; Branco, F.; Barbosa, L.; Melo, M.; Bessa, M. A multisensory virtual experience model for thematic tourism: A Port wine tourism application proposal. J. Destin. Mark. Manag. 2017, 6, 103-109. [CrossRef]

77. Clarivate Web of Science. Available online: http://www.webofknowledge.com/ (accessed on 22 May 2021).

78. Vega-Muñoz, A.; Arjona-Fuentes, J.M. Social networks and graph theory in the search for distant knowledge in the field of industrial engineering. In Handbook of Research on Advanced Applications of Graph Theory in Modern Society; Pal, M., Samanta, S., Pal, A., Eds.; IGI-Global: Hershey, PA, USA, 2020; Volume 17, pp. 397-418. [CrossRef]

79. Price, D. A general theory of bibliometric and other cumulative advantage processes. J. Assoc. Inf. Sci. 1976, 27, 292-306. [CrossRef]

80. Dobrov, G.M.; Randolph, R.H.; Rauch, W.D. New options for team research via international computer networks. Scientometrics 1979, 1, 387-404. [CrossRef]

81. Lotka, A.J. The frequency distribution of scientific productivity. J. Wash. Acad. Sci. 1926, 16, 317-321.

82. Hirsch, J.E. An index to quantify an individual's scientific research output. Proc. Natl. Acad. Sci. USA 2005, 102, 16569-16572. [CrossRef]

83. Crespo, N.; Simoes, N. Publication performance through the lens of the h-index: How can we solve the problem of the ties? Soc. Sci. Q. 2019, 100, 2495-2506. [CrossRef]

84. Sainaghi, R.; Phillips, P.; Baggio, R.; Mauri, A. Cross-citation and authorship analysis of hotel performance studies. Int. J. Hosp. Manag. 2018, 73, 75-84. [CrossRef]

85. Freeman, L.C. Centrality in social networks conceptual clarification. Soc. Netw. 1978, 1, 215-239. [CrossRef]

86. Jeon, C.-Y.; Yang, H.-W. The structural changes of a local tourism network: Comparison of before and after COVID-19. Curr. Issues Tour. 2021, 24, 3324-3338. [CrossRef]

87. Moravcsik, M.J. Applied Scientometrics: An Assessment Methodology for Developing Countries. Scientometrics 1985, 7, 165-176. [CrossRef] 
88. Frenken, K.; Hardeman, S.; Hoekman, J. Spatial scientometrics: Towards a cumulative research program. J. Inf. 2009, 3, 222-232. [CrossRef]

89. Albort-Morant, G.; Henseler, J.; Leal-Millán, A.; Cepeda-Carrión, G. Mapping the field: A bibliometric analysis of green innovation. Sustainability 2017, 9, 1011. [CrossRef]

90. Mikhaylov, A.; Mikhaylova, A.; Hvaley, D. Knowledge Hubs of Russia: Bibliometric Mapping of Research Activity. J. Scientometr. Res. 2020, 9, 1-10. [CrossRef]

91. Acevedo-Duque, Á.; Vega-Muñoz, A.; Salazar-Sepúlveda, G. Analysis of Hospitality, Leisure, and Tourism Studies in Chile. Sustainability 2020, 12, 7238. [CrossRef]

92. Köseoglu, M.A.; Okumus, F.; Putra, E.D.; Yildiz, M.; Dogan, I.C. Authorship Trends, Collaboration Patterns, and Co-Authorship Networks in Lodging Studies (1990-2016). J. Hosp. Mark. Manag. 2018, 27, 561-582. [CrossRef]

93. Lojo, A.; Li, M.; Cànoves, G. Co-authorship Networks and Thematic Development in Chinese Outbound Tourism Research. J. Chin. Tour. Res. 2019, 15, 295-319. [CrossRef]

94. Vega-Muñoz, A.; Arjona-Fuentes, J.M.; Ariza-Montes, A.; Han, H.; Law, R. In search of 'a research front' in cruise tourism studies. Int. J. Hosp. Manag. 2020, 85, 102353. [CrossRef]

95. Carabantes, A.D.; Alou, C.L. Evaluation of Research Activity in Microbiology: The Role of The Spanish Journal of Chemotherapy. Rev. Esp. Quimioter. 2019, 32, 571-576. Available online: https://seq.es/abstract/rev-esp-quimioter-2019-december-9/ (accessed on 11 January 2022).

96. Chadegani, A.A.; Salehi, H.; Yunus, M.M.; Farhadi, H.; Fooladi, M.; Farhadi, M. A comparison between two main academic literature collections: Web of science and scopus databases. Asian Soc. Sci. 2013, 9, 18-26. [CrossRef] 